\title{
CONCEPTUAL AND METHODOLOGICAL APPROACHES TO QUALITY OF LIFE - A PUBLIC HEALTH PERSPECTIVE
}

\author{
Desislava Vankova \\ ACRO, Medical University of Varna
}

\begin{abstract}
Quality of life is a major goal in the context of public health. It is important, both as a needs assessment tool and as an outcome measure in health promotion interventions. QoL has been frequently measured but seldom explicitly defined. The aim of this article is to discuss a wide range of conceptual and methodological issues related to QoL. The classical Being-Belonging-Becoming approach is presented. Further, the methodology for QoL assessment covers a wide range of topics. It involves the taxonomy of QoL definitions, a classification of QoL instruments, and recommendations how to choose the right questionnaire with the relevant psychometric properties. There is a need for more research based on carefully selected measures of QoL chosen as being of particular importance to individuals and to the hypotheses being tested. Measuring health rather than disease is a methodological challenge which has recently received more attention and should be further explored in target-setting exercises at a community level.
\end{abstract}

Keywords: quality of life, health, concept, methodology

\section{INTRODUCTION}

Quality of life (QoL) as a concept is a popular term in many fields. Public health is one of them. QoL is then quite often described as a major goal of a health promotion intervention. QoL improvement is accepted as equally important as the more objective measures like mortality and morbidity. QoL is taken by health professionals as an indication whether their services and activities result in good or bad outcomes. It is increasingly important for governments and political leaders to assure citizens that their policies will achieve better QoL for every member of

\footnotetext{
Address for correspondence:

Desislava Vankova

ACRO, Medical University-Varna

55 Marin Drinov Str.

9002 Varna, Bulgaria

e-mail:vanko07@gmail.com
}

Received: November 5, 2015

Accepted: December 1, 2015 the community. The aim of this article is to discuss a wide range of conceptual and methodological issues related to QoL. The Being-Belonging-Becoming approach is presented. Further, the methodology for QoL assessment covers a wide range of topics. It involves the taxonomy of QoL definitions, a classification of QoL instruments, a proper choice of a questionnaire with relevant psychometric properties, the administration of an instrument etc.

\section{CONCEPTUALISATION OF QOL}

QoL is the normative conceptualization of "good life" or "good society". The QoL concept is generally described as multidimensional, comprising individual's perceived physical, psychosocial and emotional functioning. QoL is different from wealth and material standard. QoL goes beyond material wealth by including also immaterial and collective components like freedom, equity, social capital, selffulfillment, happiness.

During the second half of the XX century the concept of health has been developed from the predominantly negative dimensions of the so called "five 
D's'- death, disease, disability, discomfort and dissatisfaction-research to more positive dimensions (1). QoL idea in public health has been deeply influenced by these processes and the QoL-conceptual multi-dimensional approaches of the World Health Organization (WHO). As a result, the statement from 1995 "There is no universally accepted definition of QoL" (2) is still valid in 2015. Certainly, most of the people have an idea what is good and healthy life. Therefore, finding only one definition is impossible (3-5).

The term QoL appeared for the first time in the Annals of Internal Medicine in 1966 together with the cited by JR Elkinton words of Francis Bacon': "The office of medicine is but to tune this curious harp of man's body and reduce it to harmony". This is one of the outstanding "definitions" of QoL in medicine and public health as it encompasses not only well-being and life satisfaction (the harmony inside) but also the relations of the individual with the environment e.g. the harmony between man and mankind (6).

QoL is accepted as a key heading by the US National Library of Medicine - MEDLINE Computer Search System in 1975. In 1977, QoL is approved as a concept by Index Medicus, and this is followed by a global academic and scientific acceptance. Searching with the key words 'quality of life' in MEDLINE and Pubmed we found out that from the sixties till 2005 the number of scientific articles had increased tremendously $(7,8)$. For example in Pubmed within the period 1966-2005 the number of articles comprising 'quality of life' in abstract or title is 76,698 (9).

QoL is a difficult concept with indefinable boundaries.The definition of the term QoL depends on the aims and the context of the research (10-13). Some authors consider that there are two applications of the QoL-concept while using it in health care: as a psychological assessment or as an "umbrella term" measuring different health results (13). Schalock found out in 2000 more than 100 definitions of QoL in research projects related to heath (14). On the other hand, no definition is found in many medical research projects (15) but this is not an escapism tendency. Many scientists consider QoL as indefinable and therefore prefer to investigate the dif-

${ }^{1}$ Francis Bacon (1551- 1626) - a prominent English scientist, philosopher, writer, politician. ferent dimensions of QoL rather trying to detect the undetectable e.g. the final or the only definition of QoL. The subjective approach is a major characteristic of QoL-research and one of the reasons of definitions diversity $(10,16)$. Farquhar gives the example of the difference between the medical approach towards the individual patient and the health promotional approach which employs the community focus. Every one of these approaches demands different definitions. Raphael describes the social health approach to QoL, which is interested in the structure of the community, while the psychological approach focuses on the diversity of the individual characteristics including well-being, mental health etc. (17). At the same time, the Scandinavian approach to QoL and social indicators focuses mainly on quantitative indicators and objective standards of living, which leads to a different definition of QoL.

The debate on QoL definitions goes in two main directions: 1. The different definitions which are based on the medical ill-health model and the positive WHO-definition of health, and 2. The relation and distinction between 'health' and 'QoL'. These fundamental debates stay unsolved and the result is a variety of sometimes contradictory definitions of QoL (18). The medical ill-health model definitions encompass the physical functioning of the patients and their well-being in general e.g. health is viewed as a determinant of health. On the other hand, the idea of QoL in general as a determinant of heath or health-related quality of life (HrQoL) follows WHOdefinition of health. The term 'HrQoL' is coined at the end of XX century as a result of the dynamic developments of QoL-research in medicine and public health (18-20). A relevant example of this is the US Health Department definition: „HrQoL encompasses these aspects of general QoL which have been proven to influence physical and mental health" (21). There are opponents of the idea to create a concept like HrQoL which is separate from QoL. However, HrQoL is widely used and accepted among health professionals which gives to HrQoL-concept a central role in public health research $(21,23)$. The challenge of the researchers is to formulate a clear approach to QoL for the concrete scientific project. The challenge in front of the editorial boards is to accept or reject articles which do not provide a clear conceptual approach towards QoL (10). Moreover, there 
are tendencies to merge or use interchangeably QoL or HrQoL with terms like life satisfaction, happiness, well-being, health status (22-24). Often in the context of health research, terms like 'QoL', 'HrQoL', 'subjective health', 'self-assessment of health', 'health status' are used as synonyms.

The variety of academic definitions and meanings of QoL is not a sign of conceptual weaknesses. It is generally accepted that the nature and interpretations of the QoL concept reflect the specific scientific aims of every single project (25). QoL could be defined by different indicators, domains and determinants; some authors consider QoL definitions as useless others claim being essential (26). Herewith, are summarized some QoL conceptualizations (Table 1) as a taxonomy of QoL definitions related to the different health fields.
(Fig. 1). Being encompasses the most basic aspects of who people are as individuals. Physical being is the physical health including nutrition and fitness, mobility, personal hygiene. Psychological being embodies individuals' feelings, cognitions, and evaluations of these. It focuses on self-confidence, self-control, coping with anxiety, and the initiation of positive behaviours. Spiritual Being consists of personal values and standards to live by, spiritual beliefs (which may or may not be religious by nature), transcending daily life experiences (nature, music), and celebration of special life events (birthdays and other cultural or religious events). Belonging is concerned with the fit between individuals and their various environments. Physical belonging refers to the links that people have with their physical environments (home, neighborhood, workplace, and larger com-

Table 1. Taxonomy of QoL definitions related to different health fields (Adapted from: 10, 15, 27).

\begin{tabular}{|c|c|c|}
\hline Approach & Focus & Definition \\
\hline Medical & Persons with disease & $\begin{array}{l}\text { QoL represents the functional effect of an illness and its conse- } \\
\text { quent therapy upon a patient, as perceived by the patient (28). }\end{array}$ \\
\hline $\begin{array}{l}\text { Related } \\
\text { to health }\end{array}$ & $\begin{array}{l}\text { Persons } \\
\text { with Illness or } \\
\text { disabilities }\end{array}$ & $\begin{array}{l}\text { QoL is recognized as a concept representing individual responses } \\
\text { to the physical, mental, and social of illness on daily living that in- } \\
\text { fluence the extent to which personal satisfaction with life circum- } \\
\text { stances can be achieved (29). }\end{array}$ \\
\hline $\begin{array}{l}\text { Social } \\
\text { diagnosis }\end{array}$ & $\begin{array}{l}\text { People in the } \\
\text { community }\end{array}$ & ...the adjustment and life satisfaction of community members (30) \\
\hline $\begin{array}{l}\text { Permanent } \\
\text { Disability }\end{array}$ & $\begin{array}{l}\text { Persons with devel- } \\
\text { opmental disabilities }\end{array}$ & $\begin{array}{l}\text { QoL is the outcome of individuals meeting basic needs and ful- } \\
\text { filling basic responsibilities in community settings (family, recre- } \\
\text { ational, school and work) (31). }\end{array}$ \\
\hline Ageing & $\begin{array}{l}\text { Persons above age of } \\
55 \text { years of age }\end{array}$ & $\begin{array}{l}\text { QoL is the multidimensional evaluation, by both intrapersonal and } \\
\text { social-normative criteria, of the person-environment system of an } \\
\text { individual in time past, current and anticipated (32) }\end{array}$ \\
\hline Social Indicators & $\begin{array}{l}\text { Societies and } \\
\text { communities }\end{array}$ & $\begin{array}{l}\text { Statistics of direct normative interest that facilitates concise, com- } \\
\text { prehensive and balanced judgements about the conditions of major } \\
\text { aspects of society (33). }\end{array}$ \\
\hline
\end{tabular}

\section{COMPONENTS OF QOL}

QoL is a dynamic complex constellation of interacting components. The classical Being-Belonging-Becoming (BBB) Model is presented here in order to complete the conceptual QoL-portrait (34). This is a framework which represents the three broad areas of life that a common to the human condition and are essential dimensions of human experience munity). This subcomponent includes their feelings of being at home in these environments. It also encompasses the freedom to display one's personal possessions as well as having privacy and safety in these environments. Social belonging consists of the links people have with their social environments. It focuses on meaningful relationships (partners, friends, family, friends, coworkers etc.) Community belonging embodies the connection people have with resourc- 
es typically available to members of their community and society. This includes adequate income, employment, educational and recreational programs, health and social services and community events and activities. Becoming focuses on the purposeful activities in which individuals engage in an attempt to realize their goals, aspirations and hopes. Practical becoming consists of purposeful activities that are typically done on a daily and regular basis. These activities include household choirs, paid or voluntary work, participation in school or educational programs, selfcare, and seeking out helpful services (health or social). Leisure becoming refers to leisure and recreational activities that do not necessarily have an obvious instrumental value; they promote relaxation and stress reduction. It includes activities of relatively short duration (socializing with friends, a stroll in the park, or a game of tennis) as well as cluster activities with long duration (taking vacation). Growth becoming encompasses activities that promote the development of individuals' own skills and knowledge, whether this involves formal or informal education and learning.
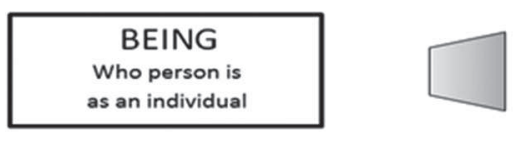

\section{Physical Psychological Spiritual}
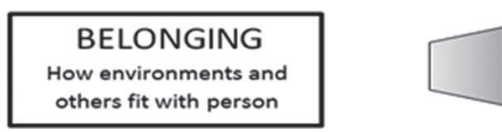

\section{Physical Social Community}
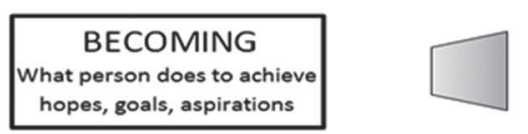

Practical Leisure Growth

Fig. 1. Conceptual framework of QoL: Essential Components and Subcomponents (34)]

A holistic instrument should include all of the components embodied in BBB- model. The conceptual discussion is finalized with the holistic WHOdefinition of individual-referenced QoL which could be the starting point for QoL- research in public health (35): "Quality of life is defined as individuals' perceptions of their position in life in the context of the culture and value systems in which they live and in relation to their goals, expectations, standards and concerns". This is a broad-ranging concept affected in a complex way by the persons' physical health, psychological state, and level of independence, social relationships and their relationship to salient features of their environment.

The nature and scope of a given concept have to be clear in order to be measured. The conceptual clarification is essential for a valid and reliable measurement. In the area of public health research the quantitative methods are still dominating but not sufficient if we need to get the "full picture". During the last 15 years the mixed-methods approach is the relevant way to combine in a scientific design the qualitative and quantitative research tools (36-38). The mixed-methods approach is a procedure which "mixes" qualitative and quantitative data in order to fulfill the scientific aims of a project (39). The meaning of the "mixing" is that neither quantitative nor qualitative methods are sufficient on its own to cover in details such complex territories like QoL and HrQoL. While used in combination they could provide a thorough analysis of a health issue $(40,41)$.

The measurement of HrQoL on an individual and population level is becoming more and more important in the policy process of defining health priorities. HrQoL detects health inequalities as it varies in the different subgroups of the community.

\section{QOL-INSTRUMENTS AS AN INNO- VATIVE HEALTH TECHNOLOGY ASSESSMENT TOOLS}

QoL-research goes beyond the methodologies of clinical medicine research (CDC, 2000). Herewith are summarized the different approaches to QoL-assessment. There are literally hundreds of QoL and HrQoL-instruments (13). The public health researchers can rely on extensive analysis of the weaknesses and strengths of a concrete instrument $(43,44)$. The development of QoL-instruments is a dynamic field. For instance, 1351 translated instruments, 933 listed patents, 712 reviews and 194 published instruments' instructions have been registered in PROQOLID database [accessed - 9h, 28.08.2015] (45). There is no consensus on the content of the universal QoL-instrument (44). Basically, there are two schools of thought which have developed in the field of QoL measurement with particular respect to the multi- 
dimensionality of the concept. One school holds that it is essential to measure QoL as a profile and strictly did not allow measurement between domains. The second school of thought notes that since people have to weight up the very diverse attributes of health to determine which one seems best it should be possible to generate a single index for each health state (46). One of the first indexes developed is Quality of Well-being Index (QWB) (47). Among the first profiles is the Sickness Impact Profile (48) and Nottingham Health Profile $(49,50)$. EQ-5D could be used as profile and as an index (46).

There are two main groups of QoL questionnaire - generic and disease-specific instruments which a created for a concrete disease. The generic instruments are intended to measure health as a holistic concept and they should be applied across different populations (51). The following steps are recommended while choosing the right instrument for the concrete public health project:

1. The instrument has to give maximum information related to subjective health. Look at the domains included in the questionnaire!

2. The questionnaire has to be validated, reliable and sensitive. Low response burden is preferable.

3. It is recommended to use an instrument which can produce index and profile data. If the questionnaire is applied elsewhere a comparison is possible. Check for a licensing fee!

\section{CONCLUSION}

QoL is a popular concept, which is more wide and subjective than specific and objective. Categories like 'QoL', 'health' and 'love' are difficult to be defined and measured (52). Therefore, if we want to measure QoL we have to make a clear scientific framework because when people assess their QoL they often assess different things with completely different measures (53). Health assessment needs a clear working definition of QoL or HrQoL, a practical instrument and a relevant study design. The public health approach to QoL comprises acceptable levels of physical and mental functioning of the individual in order to maintain its social role. QoL is also a humanistic concept as far as it values the individual's autonomy, personal sustainability and positive approach to life (54).
In health promotion research and practices, QoL and HrQoL have been increasingly acknowledged as a valid and appropriate indicator to measure health needs and outcomes, and to detect inequalities. Measuring health rather than disease is a methodological challenge which has recently received more attention and should be further explored in target-setting exercises at a community level. Wellbeing targets, including health perception have to be currently mainstreamed (55).

\section{REFERENCES}

1. Pais-Ribeiro JL. Quality of life is a primary endpoint in clinical settings. Clinical Nutrition. 2004;23:121-130.

2. Rosenberg R. Health-related quality of life between naturalism and hermeneutics. Social Science \& Medicine;1995;41:1411-15.

3. Wilson W. Correlates and avowed Subjective wellbeing. Psychological Bulletin. 1967;67.

4. Andrews FM, Withey SB. Developing Measures of perceived life quality: results from several national surveys. Social Indicators Research. 1974;1:1-26.

5. Ryff DC. Subjective well-being is everything, or is it? Exploration on the meaning of psychological well-being. Journal of Personality and Social Psychology. 1989;57(6):1069-81.

6. Katschnig H. How useful is the concept of quality of life in psychiatry? In H Katschnig, H Freeman, N Sartorius. Quality of life in mental disorders, Chichester, England, John Wiley \& Sons, 1994, pp. 3-16 in Coelho R, Ramos S, Prata J, Bettencourt P, Ferreira A, Cerqueira-Gomes, Heart Failure and Health Related Quality of Life. Clinical Practice and Epidemiology in Mental Health. 2005;1:19.

7. Albrecht GL. Subjective health assessment. In C Jenkinson (Ed.). Measuring health and medical outcomes. UCL Press: London; 1994. 7-26.

8. Wood-Dauphinee S. Assessing quality of life in clinical research from where have we come and where are we going? Journal of Clinical Epidemiology. 1999;52:355-63.

9. Moons P, Budts W, De Geest S. Critique on the conceptualization of quality of life: A review and evaluation of different conceptual approaches. International Journal of Nursing Studies. 2006;43:891-901. 
10. Farquhar M. Definitions of Quality of Life: a Taxonomy. Journal of Advanced Nursing. 1995;22(3):502.

11. 1Felce D, Perry J. Quality of Life: Its Definition and Measurement. Research in Developmental Disabilities. 1995;16(1):51.

12. Day H, Jankey SG. Lessons From the Literature. Towards a Holistic Model of Quality of Life' in Renwick, Rebecca, Brown, Ivan, and Nagler, Mark (eds) Quality of Life in Health Promotion and Rehabilitation. Conceptual Approaches, Issues and Applications, Thousand Oaks: Sage; 1996.

13. Rejeski WJ, Mihalko SL. Physical Activity and Quality of Life in Older Adults. Journals of Gerontology: Series A: Biological Sciences \& Medical Sciences. 2001;56(11):24.

14. Schalock RL. Three Decades of Quality of Life', Focus on Autism \& Other Developmental Disabilities. 2000;15(2):116-27.

15. Taillefer MC, Dupuis G, Roberge MA, Lemay S. Health-Related Quality of Life Models: Systematic Review of the Literature'. Social Indicators Research. 2003;64(307)293-323.

16. Rapley M. Quality of Life Research. A Critical Introduction. London: Sage; 2003. 84.

17. Raphael D. Defining Quality of Life: Eleven Debates Concerning Its Measurement in Renwick, Rebecca, Brown, Ivan and Nagler, Mark (eds) Quality of Life in Health Promotion and Rehabilitation: Conceptual Approaches, Issues and Applications. Thousand Oaks: Sage; 1996.

18. Haas BK. A Multidisciplinary Concept Analysis of Quality of Life, Western Journal of Nursing Research. 1999;21(6):728-742.

19. Armstrong D, Caldwell D. Origins of the Concept of Quality of Life in Health Care: A Rhetorical Solution to a Political Problem. Social Theory and Health. 2004;2(4):361-71.

20. McHorney CA. Concepts and Measurement of Health Status and Health-Related Quality of Life' in Albrecht, Gary L, Fitzpatrick, Ray and Scrimshaw Susan C (eds) Handbook of Social Studies in Health and Medicine. Thousand Oaks, New Delhi: Sage; 2000.

21. Michalos AC. Social Indicators Research and Health-Related Quality of Life Research. Social Indicators Research. 2004;65(1):27-72.
22. Meeberg GA. Quality of Life: a Concept Analysis, Journal of Advanced Nursing. 1993;18(1):32-38.

23. Haas BK. Clarification and Integration of Similar Quality of Life Concepts, IMAGE: Journal of Nursing Scholarship. 1999;31(3):4.

24. Coffman DD. Music and Quality of Life in Older Adults. Psychomusicology. 2002;18(1-2):76.

25. Schalock RL. The Concept of Quality of Life in the Lives of Persons with Mental Retardation. Paper presented at the 15th Annual Meeting of the American Association of Mental Retardation, Washington DC in Renwick Rebecca, Brown Ivan, Quality of Life in Health Promotion and Rehabilitation: Conceptual Approaches, Issues, and Applications. Sage;1996. 7.

26. Barcaccia B, Esposito G, Matarese M, Bertolaso M, Elvira M, De Marinis MG. Defining Quality of Life: A Wild-Goose Chase? Europe's Journal of Psychology. 2013;9(1).

27. Raphael D, Brown I, Renwick R, Rootman Ir. Quality of Life: What are the Implications for Health Promotion? Chapter 2 in Health Promotion and Quality of Life in Canada. Essential Reedings. Ed. By Dennis Raphael. Toronto, Ontario: Canadain Scholar Press Inc; 2010.

28. Schipper H, Clinch J, Powel V. Definitions and conceptual Issues. In Spilker, B, ed. Quality of Life in Clinical Trials. New York: Raven; 1990.

29. Bowling A. Measuring Health. Philadelphia: Open University Press \& Philadelphia; 1991.

30. Green L, Kreuter M. Health Promotion Planning. Toronto: Mayfield; 1991.

31. Schalock R. ed. Quality of Life: Perspectives and Issues. Washington, DC: American Association of Mental Retardation; 1990.

32. Lawton MP. A multidimensional view of quality of life in frail elders. In Birren J, Lubben I, Rowe J, Deuthman D, eds. The Concept and Measurement of Quality of Life in the Frail Elderly. New York: Academic Press; 1991.

33. Andrews FM. Introduction. In Andrews FM, ed. Research on the Quality of Life. Ann Arbor, MI: Institute for Social Research; 1986.

34. Renwick R, Brown I. The Centre for Health Promotion's Conceptual Approaches to Quality of Life. Being, Belonging, and Becoming. In Renwick R, Brown I, Nagler M. eds. Quality of Life in Health Promotion and Rehabilitation: Conceptu- 
al Approaches, Issues, and Applications. Thousand Oaks: Sage; 1996. 75-86.

35. WHO, WHOQOL-BREF - Instructions, Administration, Scoring and Generic Version of the Assessment WHO. Geneva; 1996. p. 5.

36. Tashakkori A, Teddlie C. (Eds.). Handbook on mixed methods in the behavioral and social sciences. Thousand Oaks, CA: Sage Publications; 2003.

37. Teddlie C, Tashakkori A, (Eds.). Foundations of mixed methods research: integrating quantitative and qualitative approaches in the social and behavioral sciences, Thousand Oaks, CA: Sage Publications; 2009.

38. Vankova D., Micheva, I., Kerekovska A. [Mixedmethod approach in medicine]. Social Medicine. 2013;21(2):16-17. Bulgarian.

39. Creswell JW. Educational research: Planning, conducting, and evaluating quantitative and qualitative approaches to research, Upper Saddle River, NJ: Merrill/Pearson Education; 2002.

40. Green JC, Caracelli VJ, Graham WF. Toward a conceptual framework for mixed-method evaluation designs. Educational Evaluation and Policy Analysis. 1989;11(3):255-274.

41. Tashakkori A, Teddlie C. Mixed methodology: Combining qualitative and quantitative approaches. Applied Social Research Methods Series. Thousand Oaks, CA: Sage Publications; 1998.

42. CDC. Measuring Healthy Days. [monograph]. Atlanta, Georgia; 2000.

43. Perry J. Measure for Measure: How Do Measures of Quality of Life Compare? British Journal of Learning Disabilities. 1995;23(4).

44. Fryback DG. Understanding and Comparing Existing Summary Measures of Health and HealthRelated Quality of Life: The State of the Art in Workshop Report: To Develop a Research Agenda and Research Resources for Health Status Assessment and Summary Health Measures; 2003.

45. Mapi [Internet]. [cited 2015]. Available from: http:// www.proqolid.org.

46. Brooks R. The EuroQol Group after 25 Years. the Netherlands: Springer; 2013.

47. Kaplan R, Bush J, Berry C. Health Status: Types of Validity and the Index of Wellbeing. Health Services Research. 1976;11:478-507.

48. Bergner M, Bobbitt RA, Pollard WE, Martin DP, Gilson BS. The sickness impact profile: val- idation of a health status measure. Med Care. 1976;14(1):57-67.

49. Hunt $\mathrm{S}$, McEwen J. The Development of a Subjective Health Indicator. Social Health and Illness. 1980;2:231-246.

50. Hunt SM, McKenna SP, McEwen J, Backett EM, Williams J, Papp E. A quantitative approach to perceived health status: A validation study. Journal of Epidemiology \& Community Health. 1980;34(4):281-6.

51. Coons SJ, Rao S, Keininger DL, et al. A Comparative Review of Generic Quality- of- Life Instruments. Pharmacoeconomics. 2000;17:13-35.

52. Green L, Kreuter M. Health Promotion planning: An Educational and Environmental Approach. Mountatin View, CA: Mayfield, 1991, p. 48.

53. Birnbacher D. Quality of Life - Evaluation or Description? Ethical Theory and Moral Practice. 1999;2(1):29.

54. Heyrman J, Van Hoeck K. Chapter 12: Health outcome measures for older people. In: Hutchinson A, McColl, Christie M, Rccalton C. (Ed) Health Outcome Measures in Primary and Out-Patient Care. United Kingdom: Harwood Academic Publishers; 1996. 167-175.

55. WHO Regional Office for Europe, 2011. Setting targets for Health 2020. WHO, Denmark. 